\title{
ANALYSIS OF FIXED ASSETS TURNOVER TO INCREASING RETURN ON ASSET AT PT. PELINDO 1 (PERSERO) BRANCH OF BELAWAN MEDAN
}

\author{
Masta Sembiring ${ }^{1}$ SE,M,Ak, Isna Ardilla SE, M.Si, Marsonang Siregar \\ Accounting Study Program Faculty of Economics and Business \\ Universitas Muhammadiyah Sumatera Utara \\ mastasembiring@umsu.ac.id ${ }^{I}$
}

\begin{abstract}
Basically every company has fixed assets used in running operations to earn business revenues. Therefore, the need for fixed asset turnover is maximal. Fix asset turnover can be done by comparing the suitability of Return on Asset. The purpose of this study is to know of fixed assets turnover in improving ROA at PT. Pelindo 1 (Persero) Branchof Belawan Medan, and to determine the factors decreasing the value of ROA at PT. Pelindo 1 (Persero) Branch of Belawan Medan. The author uses descriptive analysis method in conducting data analysis, data collection techniques are documentation and observation. The results of research and discussion conducted then it can be concluded that the fixed assets turn ofer in the company used to measure the efficiency of the use of fixed assets is said to be good enough for the company because the rotation of fixed assets generated increase Return On Asset. The decreasing ROA is caused by low operating revenues, and a decrease in net fixed assets at PT. Pelindo 1 (Persero) Belawan Branch Medan.
\end{abstract}

Keywords: Fixed Assets Turnover, Return On Assets

\section{CHAPTER I}

PT. Pelabuhan Indonesia I or often called Pelindo I is one of the Indonesian State-Owned Enterprises (SOEs) engaged in port services. Perum Pelabuhan I is one of four Perum Pelabuhan in Indonesia that manages ports cultivated and established based on Government Regulation No. 14 of 1983. PT. PELINDO I Belawan Branch company engaged in harbor and aquatic pools, services related to the guidance and delays of ships, docks, warehouses of landfills, health services, sea transport services, and container depots. The reason why the author chose PT. PELINDO I as research place is PT. PELINDO $\mathrm{I}$ is one of the largest state-owned enterprises in Indonesia. PT. PELINDO I affects the economy in Indonesia especially in Medan because it becomes the route of in and out of goods from within and outside the country. PT. PELINDO I is a container service company arranging distribution / distribution of goods from and throughout Medan. I get a recommendation where the research of one of my friends, after seeing, observing and analyzing the report, I found something that is not in accordance with the theory that I learned then I researched in PT. PELINDO I(PERSERO) AGAINST BRANCH. Based on income statement and balance sheet report at PT. PELINDO 31 December 2012 until December 31, 2016, can be seen rotationof fixed assets and ROA percentage in the table below.

Tabel 1.II

Fix Assets turnover and Return On Asset

On PT.PELINDO 1 (PERSERO) Branch of BELAWAN

\begin{tabular}{|c|c|c|}
\hline Tahun & Fix assets turnover (times) & Return On Asset $(\%)$ \\
\hline 2012 & 0,9530 & $24,7 \%$ \\
\hline 2013 & 11,043 & $35,1 \%$ \\
\hline 2014 & 11,332 & $52 \%$ \\
\hline 2015 & 16,496 & $69 \%$ \\
\hline 2016 & 17,136 & $59 \%$ \\
\hline
\end{tabular}


Based on Table I.II, the phenomenon that the authors found in this research is in 2016 where the fixed asset turnover value increased but not followed by ROA increase, while the theory according to Suad Husnan and Enny Pudjiastuti (2004: 75) "Fixed Asset Turnover Asset Turnover) is very important for the company, because it can increase rentabilitasnya, so it is clear that the higher rotation of fixed assets can play a role in determining the return on assets (ROA) ". In addition there is a decrease in the value of Return On Asset. "Return On Asset is a measure of the effectiveness of management in managing the investment, The smaller (lower) ratio, the less good, and vice versa. Cashmere (2008, p. 202). This low ratio is due to low profit margins due to low fixed asset turnover. And according to Syafrida Hani (2015, p. 119) "Efforts to increase Profitability Ratios in Return On Assets are used to generate profits by utilizing existing assets. In the company's operations, the higher ROA indicates that the company uses its assets well, all the investment used can bring high benefits ".

Based on the subject that the authors convey above, the authors are interested to lift it in the form of papers in the form of thesis, therefore the author chose the title "Analysis of Fixed Asset Turnover In Improving Return On Asset At PT.Pelindo 1 (Persero) Belawan Branch Medan"Formulation of the problem Based on the background and identification of problems that occur, the authors

\section{Formulate the problem as follows:}

1. How the rotation of fixed assets in increasing Return On Asset at PT. Pelindo 1 (Persero) Belawan Branch Medan?

2. What factors cause the decline in the value of Return On Asset in 2016 at PT. Pelindo 1 (Persero) Belawan Branch Medan?

\section{Objectives and benefits}

1. To know rotation of fixed assets in increasing Return On Asset at PT. Pelindo 1 (Persero) Belawan Branch Medan

2. To determine the factors causing the decline in the value of Return On Asset in 2016 at PT. Pelindo 1 (Persero) Belawan Branch Medan.

\section{Benefits of research}

1. For the researcher, it is expected to develop and expand the knowledge insight related to accounting economics, related to fixed asset turnover and Return On Asset.

2. For the company, to be able to provide input and suggestions that are considered necessary to help solve the problems concerning rotation of fixed assets and Return On Asset.

3. For others who want to do research on the same problem, can be input or theory in further research.

\section{CHAPTER II}

\section{THEORETICAL BASIS}

\section{Fixed Assets}

\subsection{Definition of Fixed Assets}

Fixed assets are a property owned by a company in which the wealth is obtained in a form that is ready to use or that has been built first. And its nature is also permanent and able to be used into the normal activities of the company and for a relatively long period of time and has sufficient material value Fixed assets are tangible assets held for use in the production or supply of goods or services to be rent to other parties, or for administrative purposes and is expected to be used for more than one period. (SFAS 2011, p. 162) According to Marisi P. Purba (2013, p 2), a fixed asset is defined as an asset that provides future benefits of non-monetary and long-term long leads to the value of the asset is fixed, so called afixed asset.

\section{Fixed Assets Turnover}

2.1 Definition of Fixed Assets Turnover

Turnover of fixed assets is one element in determining the high level of corporate profitability. The Company invests in fixed assets in the hope of recovering the funds invested in the assets. The rotation 
of the fixed assets will be fully recovered by the company within a few years and gradually return through depreciation. The amount of funds bound in fixed assets will gradually decrease according to the depreciation method used by the company. The rotation of fixed assets can determine the level of profitability of the company. Agnes Sawir (2005: 17) states, "The fixed asset turnover ratio measures the effectiveness of use funds embedded in fixed assets such as factories and equipment in order to generate sales or how much net sales are generated by each dollar invested in fixed assets ". Brigham and Houston (2010: 138) "Fixed Asset Turnover Ratio (Fixed Asset Turnover Ratio) is used to measure how effectively firms using the plant and its equipment ". By looking at our ratio we can assets the efficiency and effectiveness of fixed assets in increasing revenue

\section{Return On Assets (ROA)}

3.1 Understanding Return On Assets

Return on assets is one of profitability ratios. In the analysis of financial statements, this ratio is most often highlighted, because it is able to show the success of the company in generating profits. ROA is able to measure the company's ability to generate profits in the past to then be projected in the future.

\section{CHAPTER III}

\section{RESEARCH METHOD.}

The research approach used by the authors in this study is a descriptive approach. This descriptive research approach aims to analyze the phenomenon that occurs in the real situation at the time of the study. This research is a research that collects, compiles, classifies and interpret the data so as to know a clear picture of the problem studied at PT. Pelindo 1 (Persero) Branch Belawan Medan with the aim to explain problem-solving based on data by presenting and interpreting research results.

\section{CHAPTER IV}

\section{RESEARCH RESULT AND DISCUSSIONA.}

Research Results

Description of Research Data

Tabel IV.I

Operating Revenues, Net Fix Assets, Profit before Tax, dan Total Assets

On PT. Pelindo 1 (Persero) branch ofBelawan Medan

\begin{tabular}{|c|c|c|c|c|}
\hline No & Operating revenues & Net Fix Assets & Profit Before Tax & Total Assets \\
\hline 2012 & 296.317 .528 .951 & 310.908 .188 .220 & 93.089 .246 .703 & 376.656 .234 .691 \\
\hline 2013 & 385.349 .085 .132 & 348.950 .626 .414 & 146.193 .868 .765 & 415.956 .290 .977 \\
\hline 2014 & 468.973 .766 .768 & 351.916 .733 .188 & 205.653 .220 .552 & 394.846 .079 .968 \\
\hline 2015 & 558.278 .609 .551 & 338.415 .105 .170 & 274.767 .530 .934 & 394.846 .079 .968 \\
\hline 2016 & 532.575 .634 .445 & 310.793 .392 .278 & 239.016 .749 .594 & 404.813 .177 .670 \\
\hline
\end{tabular}

Viewed from the above table, operating revenues in the company increased from 2012 to 2015, and once decreased in 2016. Decreased business revenues can reduce profits to be generated companies, where profits will symbolize the success of the company as a way of determining the achievement of the target operation. And on the net fixed assets decrease in 2015 and 2016, the addition of net fixed assets conducted by the company is aimed at expectations with the addition of the company is able to increase the optimal revenue as a measuring tool to increase revenue, which will have a direct impact on increasing the value of ROA. Because if the company continues to use the assets that are old or not add assets owned, resulting in decreased quality of products and services to be generated. Profit is a benchmark company to determine whether or not the company's effectiveness in what is generated from operating activities undertaken. In the company's profit before tax, where profit before tax increased in 2012 to 2015 , and once decreased in 2016. The decline that occurs can affect the value of 
ROA, because the smaller the value of profits will impact less well with its ROA. Total assets are a good balance where by with the increase in total assets, the company can expect a higher rate of return on the company's assets. Can be seen in the table, total assets in 2013 increased from the previous year, and in 2014 and 2015 decreased, and in 2016 again increased. The addition of the total assets may not necessarily increase the optimal profit from the previous year. From the description above data can be said that the fixed assets are company property in the form of physical aims to assist the company in the framework of the normal activities of the company.

\section{Fixed Assets Turnover}

Fixed asset turnover can be calculated by dividing revenues with fixed assets. It can be seen from the calculation of fixed asset turnover conducted for 5 years from 2012 until 2016 at PT. Pelindo 1 (Persero) Belawan Branch Medan.Obtained calculation as follows:

\begin{tabular}{|c|c|c|}
\hline \multicolumn{3}{|c|}{ Tabel 1.II } \\
\multicolumn{3}{|c|}{ Fix Assets turnover and Return On Asset } \\
\hline Tahun & Fix PT.PELINDO 1 (PERSERO) Branch of BELAWAN \\
\hline 2012 & 0,9530 & Return On Asset (\%) \\
\hline 2013 & 11,043 & $24,7 \%$ \\
\hline 2014 & 11,332 & $35,1 \%$ \\
\hline 2015 & 16,496 & $52 \%$ \\
\hline 2016 & 17,136 & $69 \%$ \\
\hline
\end{tabular}

From the table above can be seen that the return on assets in 2013 until 2015 an increase, in 2013 return on assets of $35.1 \%$, return on assets increased $10.4 \%$ from 2012 , it happens because of an increase in profit before tax and total assets. Income before tax increase Rp. 53,104,622,062 from the previous year, and total assets increased by Rp.39.300.056.286 from 2012. In 2014 return on assets of $52 \%$, an increase in return on asset value of $16.9 \%$ from 2013. It also happens due to an increase in profit before tax of Rp. 59,459,351,787 from 2013. Although in 2014 total assets decreased from the previous year, and decreased total assets amounted to Rp.21.110.211.009. In 2015 the increase also occurs on the value of return on assets, by 2015 ROA by $69 \%$ increase of $17 \%$ from 2014 . In that increase the profit before taxes and total assets back up simultaneously. Increase in profit before tax and total assets in 2015 from 2014 increased by Rp.69,114,310,382 for profit before tax, and for total assets increased by Rp.3.337.369.156. And by 2016 return on assets has decreased, the value of return on assets in 2016 by $59 \%$, down by $10 \%$ from the previous year. This happens because the profit before tax in 2016 has decreased and the total share of its assets increased. Profit before taxes decreased by Rp.35,750,781,340 from 2015, and in total assets increased by Rp.6,629,728,546. This shows that the company has not been able to manage its total assets effectively in reducing the level of losses experienced by the company let alone increase profits.

\section{RUJUKAN}

Agnes Sawir. 2005. Analisis Kinerja Keuangan Dan Perencanaan Keuangan Perusahaan, Jakarta, PT. Gramedia Pustaka Utama.

Ari Bramasto. 2011. Analisis Perputaran Aktiva Tetap Dan Perputaran Piutang Dalam Meningkatkan Return On Asset Pada PT. POS Indonesia. Bandung, Jurnal Ekonomi Vol.9 Hal.2

Aswar Amin Pardomuan Simamora. 2017. Analisis Struktur Aktiva dan Pertumbuhan Laba Dalam Meningkatkan Return On Asset Pada PT. Tiga Raksa Satria Medan. Medan, Fakultas Ekonomi UMSU

Brigham dan Houston. 2010. Dasar - Dasar Manajemen Keuangan Buku 1 (Edisi II), Jakarta, Penerbit Salemba Empat 
Eduardus Tandeilin. 2010. Portofolio dan Investasi Teori Dan Aplikasi (1th Ed). Yogyakarta, Kanisius Egi Febriani. 2006. Analisis Perputaran Total Aktiva Dalam Meningkatkan Profitabilitas pada PT Angkasa Pura II. Jurnal Ilmiah Ranggagading Vol.6 No.2 Oktober 2006

IAI .2011. Standar Akuntansi Keuangan, Jakarta, Salemba 4.

Kasmir. 2008. Bank dan lembaga keuangan lainnya, Jakarta, Edisi Revisi. PT. Raja Grafindo Persada. 2010. Pengantar Manajemen Keuangan, Jakarta, Kencana Prenada Media Group

L.M. Samryn. 2015. Pengantar Akuntansi. Jakarta, Rajawali Pers

Lestari dan Sugiarto. 2007. Kinerja Bank Devisa Dan Bank Non Devisa Dan Faktor-Faktor Yang Mempengaruhinya. Proceding PESAT (Psikologi, Ekonomi, Sastra, Arsitek \& Sipil). Vol. 2 Fakultas Ekonomi, Universitas Gunadarma

Malayahati Siambaton. 2015. Analisis Perputaran Aktiva Tetap Dalam Meningkatkan Return On Asset Pada PT. PLN (Persero) Pembangkitan Sumatera Utara Bagian Utara. Medan, Fakultas Ekonomi UMSU

Mardiyanto. 2009. Intisari Manajemen Keuangan, Jakarta, PT. GRASINDO

Munawir. 2007. Analisa Laporan Keuangan (Edisi 4 ed) Yogyakarta, Liberty 2010. Analisa Laporan Keuangan, Yogyakarta, Liberty.

Purba marisi. P. 2013. Akuntansi Keuangan Aset Tetap Dan Aset Tak Berwujud, Yogyakarta, Penerbit Graha Ilmu. 